\title{
Pedoman Pelaksanaan Pemeriksaan Barang dan Jasa Konstruksi Berdasarkan Keteknikan, Kesehatan dan Keselamatan Kerja (K3), Perlindungan Sosial Tenaga Kerja, Tata Lingkungan (AMDAL) dan Manfaat bagi Masyarakat
}

\author{
Yusril \\ Satuan Kerja Nasional Jalan III Kalimantan Tengah \\ Balai Besar Pelaksanaan Jalan NasionalXI
}

\begin{abstract}
ABSTRAK. Departemen Pekerjaan Umum mempunyai peranan penting dan strategis dalam menyediakan barang dan jasa bidang pekerjaan umum, yang berfungsi mendukung pertumbuhan dan perkembangan berbagai bidang, terutama bidang ekonomi, sosial, dan budaya. Pengadaan barang dan jasa bidang pekerjaan umum harus melalui proses penyelenggaraan pekerjaan konstruksi, meliputi tahap perencanaan pekerjaan konstruksi, pelaksanaan beserta pengawasan pekerjaan konstruksi, dan operasi serta pemeliharaan penyelenggaraan pekerjaan konstruksi oleh Departemen Pekerjaan Umum. Dalam menyediakan barang dan jasa bidang pekerjaan umum harus memenuhi ketentuan Undang-undang Nomor 18 Tahun 1999 tentang Jasa Konstruksi dan Peraturan Pelaksanaannya yang menyatakan bahwa penyelenggara pekerjaan konstruksi wajib mewujudkan hasil pekerjaan konstruksi yang handal dan bermanfaat dengan memenuhi ketentuan tertib penyelenggaraan pekerjaan konstruksi, meliputi: (1) keteknikan, meliputi persyaratan keselamatan umum, konstruksi bangunan, mutu hasil pekerjaan, mutu bahan dan/atau komponen bangunan, dan mutu peralatan sesuai dengan standar atau norma yang berlaku; (2) keamanan, keselamatan, dan kesehatan tempat kerja konstruksi sesuai dengan peraturan perundang-undangan yang berlaku; (3) perlindungan sosial tenaga kerja dalam pelaksanaan pekerjaan konstruksi sesuai dengan peraturan perundang-undangan yang berlaku; (4) tata lingkungan setempat dan pengelolaan lingkungan hidup sesuai dengan peraturan perundangundangan yang berlaku; dan (5) manfaat untuk masyarakat sesuai dengan perencanaan kelayakan. Untuk menjamin tugas Departemen Pekerjaan Umum dalam menyediakan infrastuktur bidang pekerjaan umum yang handal dan bermanfaat, wajib memenuhi tertib penyelenggaraan pekerjaan konstruksi, diperlukan pedoman pelaksanaan pemeriksaan persediaan barang dan jasa konstruksi berdasarkan keteknikan, kesehatan dan keselamatan kerja (K3), perlindungan sosial tenaga kerja, tata lingkungan (AMDAL) dan manfaat bagi masyarakat sebagai acuan pengawasan fungsional.
\end{abstract}

Kata kunci : barang, jasa, konstruksi, keteknikan

\section{PENDAHULUAN}

Dalam pembangunan nasional, Departemen Pekerjaan Umum mempunyai peranan penting dan strategis dalam menyediakan infrastruktur bidang pekerjaan umum yang berfungsi mendukung pertumbuhan dan perkembangan berbagai bidang, terutama bidang ekonomi, sosial, dan 
budaya. Penyediaan infrastrukstur bidang pekerjaan umum harus melalui proses penyelenggaraan pekerjaan konstruksi meliputi tahap perencanaan pekerjaan konstruksi, pelaksanaan beserta pengawasan pekerjaan konstruksi, dan operasi serta pemeliharaan. Penyelenggaraan pekerjaan konstruksi oleh Departemen Pekerjaan Umum dalam menyediakan infrastruktur bidang pekerjaan umum harus memenuhi ketentuan Undang-undang Nomor 18 Tahun 1999 tentang Jasa Konstruksi dan Peraturan Pelaksanaannya yang menyatakan bahwa penyelenggara pekerjaan konstruksi wajib mewujudkan hasil pekerjaan konstruksi yang handal dan bermanfaat dengan memenuhi ketentuan tertib penyelenggaraan pekerjaan konstruksi, meliputi (1) keteknikan, meliputi persyaratan keselamatan umum, konstruksi bangunan, mutu hasil pekerjaan, mutu bahan dan/atau komponen bangunan, dan mutu peralatan sesuai dengan standar atau norma yang berlaku; (2) keamanan, keselamatan, dan kesehatan tempat kerja konstruksi sesuai dengan peraturan perundang-undangan yang berlaku; (3) perlindungan sosial tenaga kerja dalam pelaksanaan pekerjaan konstruksi sesuai dengan peraturan perundang-undangan yang berlaku; (4) tata lingkungan setempat dan pengelolaan lingkungan hidup sesuai dengan peraturan perundang-undangan yang berlaku; dan (5) manfaat untuk masyarakat sesuai dengan perencanaan kelayakan.

\section{TUJUAN PEMERIKSAAN}

Tujuan pemeriksaan konstruksi adalah untuk menjaga tercapainya tertib penyelenggaraan dan hasil pekerjaan konstruksi baik fisik maupun non fisik meliputi aspek perencanaan konstruksi, pengadaan, manajemen pelaksanaan dan pengendalian kontrak di lingkungan Departemen Pekerjaan Umum.

\section{SASARAN PEMERIKSAAN}

Sasaran pemeriksaan konstruksi untuk memastikan bahwa:

1. Proses perencanaan pekerjaan konstruksi sudah dilakukan secara taat, lengkap dan benar sesuai ketentuan yang berlaku dengan analisis yang menghasilkan perencanaan yang tepat (proper design);

2. Proses pemilihan penyedia jasa sudah dilakukan secara taat, lengkap dan benar sehingga menghasilkan penyedia jasa yang berkualifikasi sesuai kebutuhan paket yang diadakan;

3. Proses pelaksanaan pekerjaan konstruksi sudah dilakukan secara taat, lengkap dan benar sehingga menghasilkan produk pekerjaan konstruksi yang berkualitas, hemat/ ekonomis dan bermanfaat.

\section{RUANG LINGKUP PEMERIKSAAN} meliputi:

Ruang lingkup pemeriksaan konstruksi

1. Pemeriksaan pemenuhan terhadap tingkat risiko;

2. Pemeriksaan perencanaan pekerjaan konstruksi berdasarkan atas SNI, standar keteknikan yang ada dan value engineering serta manfaat pembangunan terhadap masyarakat sesuai dengan perencanaan kelayakannya;

3. Pemeriksaan pemilihan penyedia jasa yang berkualifikasi, dengan harga terendah, terevaluasi dan tanpa penyimpangan yang penting dan pokok;

4. pemeriksaan sistem pengendalian manajemen dari segi waktu, biaya dan kualitas;

5. Pemeriksaan pelaksanaan paket kegiatan dalam pemenuhan persyaratan keteknikan, keselamatan umum, perlindungan social tenaga kerja dan tata lingkungan;

6. Pemeriksaan tertib administrasi keuangan;

7. Pemeriksaan pencapaian manfaat dengan melakukan analisis terhadap fungsi konstruksi setelah penyerahan kedua serta keterpaduan program dengan sektor lainnya;

8. Pemeriksaan risiko kegagalan konstruksi dan kegagalan bangunan.

\section{KETENTUAN PENYELENGGARAAN PEMERIKSAAN}

Dalam pedoman pelaksanaan pemeriksaan persediaan barang dan jasa konstruksi berdasarkan analisis mengenai dampak lingkungan (AMDAL) yang dimaksud dengan: 
1. Pekerjaan Konstruksi adalah keseluruhan atau sebagian rangkaian kegiatan perencanaan dan/atau pelaksanaan beserta pengawasan yang mencakup pekerjaan arsitektural, sipil, mekanikal, elektrikal dan tata lingkungan masingmasing beserta kelengkapannya untuk mewujudkan suatu bangunan atau bentuk fisik lain.

2. Pekerjaan Konstruksi dengan Risiko Tinggi mencakup pekerjaan konstruksi yang pelaksanaannya berisiko sangat membahayakan keselamatan umum, harta benda, jiwa manusia dan lingkungan.

3. Pekerjaan Konstruksi dengan Risiko Sedang mencakup pekerjaan konstruksi yang pelaksanaannya dapat berisiko membahayakan keselamatan umum, harta benda, dan jiwa manusia.

4. Pekerjaan Konstruksi dengan Risiko Kecil, mencakup pekerjaan konstruksi yang pelaksanaannya tidak membahayakan keselamatan umum dan harta benda.

5. Pemeriksaan Konstruksi adalah pemeriksaan keteknikan sebagaimana dimaksud dalam Permen PU No. 14/PRT/M/2007 tentang Pedoman Umum Pemeriksaan Terhadap Penyelenggaraan Pekerjaan Konstruksi Bidang Sarana dan Prasarana Pekerjaan Umum baik fisik maupun non fisik dengan penekanan terhadap tertib penyelenggaraan dan hasil pekerjaan konstruksi yang meliputi aspek perencanaan pekerjaan konstruksi, pengadaan, manajemen pengendalian, pelaksanaan kontrak yang didukung kompetensi penyelenggara.

6. Tertib Penyelenggaraan Pekerjaan Konstruksi adalah pemenuhan persyaratan ketentuan pasal 30 Peraturan Pemerintah No. 29 tahun 2000 tentang Penyelenggaraan Pekerjaan konstruksi.

7. Pengadaan adalah rangkaian kegiatan mulai dari persiapan, pemilihan penyedia jasa, penandatanganan kontrak, pelaksanaan kontrak sampai dengan penyerahan akhir pekerjaan.

8. Jasa konstruksi adalah layanan jasa konsultansi perencanaan pekerjaan konstruksi, layanan jasa pelaksanaan pekerjaan konstruksi, dan layanan jasa konsultansi pengawasan pekerjaan konstruksi.

9. Kegagalan Konstruksi adalah keadaan hasil pekerjaan konstruksi yang tidak sesuai dengan spesifikasi pekerjaan sebagaimana disepakati dalam kontrak kerja konstruksi baik sebagian maupun keseluruhan sebagai akibat kesalahan pengguna jasa dan /atau penyedia jasa.

10. Kegagalan Bangunan adalah keadaan bangunan yang tidak berfungsi, baik secara keseluruhan maupun sebagian dari segi teknis, manfaat, keselamatan dan kesehatan kerja, dan/atau keselamatan umum sebagai akibat penyedia jasa dan /atau pengguna jasa setelah penyerahan akhir pekerjaan konstruksi.

11. Pekerjaan Kompleks adalah pekerjaan yang memerlukan teknologi tinggi dan/atau mempunyai risiko tinggi dan/atau menggunakan peralatan khusus dan/atau bernilai di atas Rp. 50.000.000.000,- (lima puluh miliar rupiah)

12. Pekerjaan dengan Teknologi Tinggi adalah pekerjaan konstruksi yang dalam pelaksanaannya banyak menggunakan peralatan berat dan tenaga ahli maupun tenaga terampil.

13. Pekerjaan dengan Total Nilai Besar adalah pekerjaan pada segmen pasar non kecil.

14. Manajemen Konstruksi adalah tata kelola penyelenggaraan pekerjaan konstruksi yang meliputi tahap perencanaan serta tahap pelaksanaan dan pengawasannya.

15. Value Engineering adalah cara efektif yang berorientasi teknis dengan melakukan improvisasi (pengembangan) desain dan/atau pelaksanaan dan/atau konstruksi mengefektifkan berbagai pengadaan pekerjaan konstruksi

16. Penyelenggara Konstruksi adalah Pengguna Jasa Jasa

17. Penyelenggara yang Berkualifikasi adalah penyelenggara yang memahami kaidah pekerjaan konstruksi antara lain : metode pelaksanaan (construction method), metode kerja (work method), analisis pendekatan teknis (technical 
analysis) yang didukung sumber daya yang memadai.

18. The lowest evaluated substantially responsive bid, from responsible bidder Responsible Bidder adalah penawar yang diperoleh dari hasil penilaian kualifikasi penyedia jasa yang meliputi kompetensi dan kemampuan usaha dari aspek baik pengalaman perusahaan, kemampuan keuangan, maupun kemampuan teknis, sesuai persyaratan yang ditentukan dalam dokumen kualifikasi.

The lowest evaluated substantially responsive bid adalah penawaran terendah yang setelah dilakukan evaluasi adminstrasi, teknis dan kewajaran harga memenuhi persyaratan yang ditentukan dalam dokumen lelang termasuk addendum, tanpa penyimpangan yang penting/pokok.

19. Pelaksanaan (Construction Method) adalah cara pelaksanaan pekerjaan konstruksi berdasarkan urutan kegiatan yang logis, realistis dan dapat dilaksanakan dengan menggunakan sumber daya secara efisien.

20. Metode Kerja (Work Method) adalah cara pelaksanaan kegiatan pekerjaan dengan susunan bahan, peralatan dan tenaga manusia yang menghasilkan produk pekerjaan dalam bentuk satuan volume dan biaya.

21. Analisis Pendekatan Teknis (Technical Analysis) adalah perhitungan pendekatan teknis atas kebutuhan sumber daya material, tenaga kerja, dan peralatan untuk melaksanakan dan menyelesaikan pekerjaan konstruksi.

22. Peralatan adalah peralatan berat (heavy equipment) yang digunakan secara individual atau kelompok alat (fleet).

23. Sistem Pengendalian Manajemen (SPM) adalah system pengendalian pelaksanaan kegiatan terhadap 8 (delapan) unsur yaitu: pengorganisasian, personil, kebijakan, perencanaan, prosedur, pencatatan, pelaporan, supervisi dan review intern.

24. Tenaga Kerja adalah setiap orang yang mampu melakukan pekerjaan baik di dalam maupun di luar hubungan kerja, guna menghasilkan jasa atau barang untuk memenuhi kebutuhan masyarakat.

25. Asuransi Tenaga Kerja adalah perjanjian asuransi dengan maksud untuk mengadakan suatu perlindungan bagi tenaga kerja dalam bentuk santunan berupa uang sebagai pengganti sebagian dan penghasilan yang hilang atau berkurang dan pelayanan sebagai akibat peristiwa atau keadaan yang dialami oleh tenaga kerja berupa kecelakaan kerja, sakit, meninggal dunia, dan jaminan kesehatan pekerja.

26. Kecelakaan Kerja adalah kecelakaan yang terjadi berhubung dengan hubungan kerja, termasuk penyakit yang timbul karena hubungan kerja, demikian pula kecelakaan yang terjadi dalam perjalanan berangkat dari rumah menuju tempat kerja, dan pulang ke rumah melalui jalan yang biasa atau wajar dilalui.

27. Pemeliharaan Kesehatan adalah upaya penanggulangan dan pencegahan gangguan kesehatan yang memerlukan pemeriksaan, pengobatan, dan/atau perawatan.termasuk kehamilan dan persalinan.

28. Penyelenggaraan Asuransi Tenaga Kerja adalah upaya untuk memberikan perlindungan kepada tenaga kerja melalui program jaminan sosial tenaga kerja yang pengelolaannya dapat dilaksanakan dengan mekanisme asuransi.

29. Pengelolaan Lingkungan Hidup adalah upaya terpadu untuk melestarikan fungsi lingkungan hidup yang meliputi kebijakan penataan, pemanfaatan, pengembangan, pemeliharaan, pemulihan, pengawasan, dan pengendalian lingkungan hidup.

30. Perusakan Lingkungan Hidup adalah tindakan yang menimbulkan perubahan langsung atau tidak langsung terhadap sifat fisik dan/atau hayatinya yang mengakibatkan lingkungan hidup tidak berfungsi lagi dalam menunjang pembangunan yang berkelanjutan.

31. (AMDAL) adalah kajian mengenai dampak besar dan penting suatu usaha dan/atau kegiatan yang direncanakan pada lingkungan hidup yang diperlukan 
bagi proses pengambilan keputusan tentang penyelenggaraan usahadan/atau kegiatan yang meliputi :

a. Dokumen Kerangka Acuan Analisis Dampak Lingkungan Hidup (KAANDAL)

b. Dokumen Analisis Dampak Lingkungan Hidup (ANDAL)

c. Dokumen Rencana Kelola Lingkungan Hidup (RKL)

d. Dokumen Rencana Pemantauan Lingkungan Hidup (RPL)

e. Dokumen Ringkasan Eksekutif

\section{A. Kriteria Pemeriksaan Konstruksi}

Pemeriksaan konstruksi diutamakan terhadap paket pekerjaan yang nilai totalnya besar dan/atau kompleks dan/atau berteknologi tinggi dan/atau berisiko tinggi dan/atau bersifat strategis untuk kinerja Departemen Pekerjaan Umum sebagaimana ditetapkan oleh Inspektur Jenderal.

\section{B. Persyaratan Auditor}

Kriteria Persyaratan Auditor adalah sebagai berikut:

1. Persyaratan auditor yang melakukan pemeriksaan konstruksi sesuai dengan ketentuan Permen 14 Tahun 2007 Bab III Bagian Kesatu Pasal 5 angka (3) adalah Auditor yang memiliki pendidikan keteknikandan/atau pengalaman yang sesuai dan/atau auditor yang telah memiliki sertifikat pendidikan pelatihan keteknikan pekerjaan umum bagi pemeriksa.

2. Inspektur Jenderal dapat menugaskan tenaga ahli keteknikan tertentu dan nara sumber dalam rangka menjamin efektivitas pemeriksaan.

\section{Supervisor dan Susunan Keanggotaan Tim Pemeriksa Konstruksi}

Supervisor dan susunan keanggotaan tim pemeriksa konstruksi adalah sebagai berikut:

1. Inspektur Jenderal menugasi Inspektur sebagai Supervisor untuk mengawasi dan mengendalikan kegiatan pemeriksaan.

2. Susunan keanggotaan Tim Pemeriksa Konstruksi terdiri dari :
a. Pengendali Mutu;
b. Pengendali Teknis;
c. Ketua Tim;
d. Anggota Tim;

3. Tim dapat dibantu oleh Tenaga Ahli dan/atau Nara Sumber.

4. Dalam hal Pengendali Mutu dan/atau Pengendali Teknis belum difungsikan, maka perannya digantikan oleh Supervisor.

\section{Tugas, Tanggung Jawab dan Kewenangan Tim Pemeriksa Konstruksi}

Tugas, tanggung jawab dan kewenangan tim pemeriksa konstruksi adalah sebagai berikut:

\section{Pengendali Mutu:}

a. Melaksanakan penugasan dan rencana kegiatan pemeriksaan dari Inspektur Jenderal;

b. Membahas persiapan kegiatan pemeriksaan dengan tim;

c. Mengarahkan survei pendahuluan;

d. Membuat Program Pemeriksaan;

e. Mengkomunikasikan program pemeriksaan kepada Pengendali Teknis dan Ketua Tim;

f. Berkonsultasi/berdiskusi dengan Supervisor mengenai hal - hal yang berhubungan dengan masalah pemeriksaan;

g. Melakukan evaluasi dan pengawasan terhadap pelaksanaan tugas;

h. Menyampaikan hasil evaluasi dalam pertemuan monitoring yang dilakukan oleh Inspektur Jenderal;

i. Menetapkan perubahan/penyesuaian terhadap Program Kerja Pemeriksaan;

j. Meninjau ulang konsep Laporan Hasil Pemeriksaan;

k. Mengevaluasi pelaksanaan tugas pemeriksaan;

1. Memaraf LHP;

m. Menilai kinerja Pengendali Teknis dan Ketua Tim;

n. Bertanggung jawab atas mutu hasil pemeriksaan; dan

o. Bertanggung jawab kepada Inspektur Jenderal melalui Supervisor. 


\section{Pengendali Teknis:}

a. Mempelajari dan membahas penugasan pemeriksaan dengan Pengendali Mutu;

b. Membuat rincian jadwal waktu pemeriksaan;

c. Mengarahkan penyusunan Program Kerja Pemeriksaan;

d. Menyelenggarakan konsultasi/diskusi dengan Pimpinan, Ketua Tim dan Anggota Tim;

e. Mengajukan usul revisi Program Pemeriksaan;

f. Melakukan pengawasan atas pelaksanaan tugas pemeriksaan;

g. Meninjau ulang atas konsistensi pelaksanaan tugas pemeriksaan dengan program kerja pemeriksaan yang dilakukan oleh Ketua Tim dan Anggota Tim;

h. Meninjau ulang atas konsep LHP;

i. Melakukan evaluasi kinerja Ketua Tim dan Anggota Tim;

j. Bertanggung jawab atas teknik pelaksanaan pemeriksaan tim; dan

k. Bertanggung jawab kepada Pengendali Mutu.

\section{Ketua Tim:}

a. Melaksanakan survey pendahuluan, menganalisis data, membuat Program Kerja Pemeriksaan;

b. Mengkomunikasikan Program Kerja Pemeriksaan kepada Anggota Tim, Tenaga Ahli dan/atau Nara Sumber

c. Memberikan tugas kepada anggota untuk melakukan pemeriksaan;

d. Melakukan pengawasan atas pelaksanaan tugas Anggota Tim, Tenaga Ahli dan/atau Nara Sumber;

e. Mengendalikan pemeriksaan sesuai dengan Program Kerja Pemeriksaan dan perubahannya yang telah disetujui oleh Pengendali Teknis;

f. Melakukan pemeriksaan sesuai dengan Program Kerja Pemeriksaan;

g. Meninjau ulang Kertas Kerja Pemeriksaan;

h. Meninjau ulang atas konsistensi tugas pemeriksaan dengan Program Kerja Pemeriksaan;

i. Bertanggung jawab atas penyusunan Berita Pemeriksaan (BP); j. Bersama Anggota Tim melakukan pembahasan Berita Pemeriksaan (BP) dengan auditi;

k. Menyusun simpulan hasil pemeriksaan;

1. Menyusun konsep, menyelesaikan, dan menandatangani LHP;

m. Melakukan evaluasi kinerja Anggota Tim;

n. Bertanggung jawab atas pelaksanaan kegiatan pemeriksaan; dan

o. Bertanggung jawab kepada Pengendali Teknis.

\section{Anggota Tim:}

a. Mempelajari Program Kerja Pemeriksaan;

b. Membahas dan menerima penugasan dari Ketua Tim;

c. Melaksanakan pemeriksaan sesuai dengan Program Kerja Pemeriksaan;

d. Membuat Kertas Kerja Pemeriksaan dan simpulan hasil pemeriksaan

e. Menyusun konsep Berita Pemeriksaan (BP) sesuai tanggung jawabnya;

f. Bertanggung jawab atas mutu temuan pemeriksaan; dan

g. Bertanggung jawab kepada Ketua Tim

\section{Tenaga Ahli Keteknikan:}

a. Mengumpulkan dan menganalisis data serta melakukan pengamatan dan pengujian secara profesional termasuk membuat penilaian tentang perlu atau tidaknya dilakukan value engineering terhadap desain, pelaksanaan konstruksi, dan pemenuhan terhadap persyaratan keteknikan dalam rangka tertib penyelenggaraan pekerjaan konstruksi, serta membuat penilaian terhadap fungsi konstruksi setelah FHO;

b. Memberikan masukan dan rekomendasi berdasarkan hasil kerjanya secara tertulis kepada Ketua Tim;

c. Bertanggung jawab atas mutu hasil kerjanya; dan

d. Bertanggung jawab kepada Ketua Tim.

\section{Nara Sumber:}

a. Memberikan masukan secara tertulis dalam bentuk perumusan hasil audit.

b. Memberikan masukan substansi bidang tertentu sesuai dengan kompetensinya. 
c. Bertanggung jawab atas masukannya kepada pemberi tugas.

\section{PERSIAPAN PEMERIKSAAN}

\section{A. Survei Pendahuluan/Desk Audit}

Survei pendahuluan dilakukan terhadap paket yang diperiksa, sesuai Surat Perintah Tugas, dimaksudkan untuk mendeteksi kemungkinan adanya penyimpangan awal dalam pelaksanaan paket yang akan diperiksa. Data yang diperlukan antara lain: Perencanaan pekerjaan konstruksi, Proses Pemilihan Penyedia Jasa, Pre Award Meeting,PreConstruction Meeting, Program Mutu, Pengendalian Pelaksanaan, Justifikasi Teknis, keterpaduan program dengan sektor lainnya dan dokumen lainnya.

\section{B. Evaluasi Pelaksanaan Sistem Pengendalian Manajemen (SPM)}

Evaluasi SPM terhadap pelaksanaan sistem pengendalian pelaksanaan kegiatan mencakup 8 (delapan) unsur yaitu: pengorganisasian, personil, kebijakan, perencanaan, prosedur, pencatatan, pelaporan, supervisi dan review intern. Evaluasi SPM dimaksudkan untuk menentukan fokus pemeriksaan.

\section{Penyusunan Program Kerja dan Jadwal}

Program Kerja Pemeriksaan (PKP) disusun untuk paket yang akan diperiksa sesuai Surat Perintah Tugas berdasarkan hasil evaluasi SPM dengan tingkat kedalaman pemeriksaan sesuai urutan prioritas.

\section{PELAKSANAAN PEMERIKSAAN}

\section{A. Pemeriksaan Pemenuhan Persyaratan Penyelenggaraan Pekerjaan Konstruksi Terhadap Setiap Tingkat Risiko}

Sesuai dengan ketentuan Peraturan Pemerintah No. 29 tahun 2000 tentang Penyelenggaraan Jasa Konstruksi, penyelenggaraan pekerjaan konstruksi wajib dimulai dengan tahap perencanaan dengan ketentuan :

1. Dalam perencanaan pekerjaan konstruksi dengan pekerjaan risiko tinggi harus dilakukan pra studi kelayakan, studi kelayakan, perencanaan umum, dan perencanaan teknik.

2. Dalam perencanaan pekerjaan konstruksi dengan pekerjaan risiko sedang harus dilakukan studi kelayakan, perencanaan umum dan perencanaan teknik.

3. Dalam perencanaan pekerjaan konstruksi dengan pekerjaan risiko kecil harus dilakukan perencanaan teknik.

Untuk tahap pelaksanaan beserta pengawasannya, dengan ketentuan:

1. Lingkup tahap pelaksanaan beserta pengawasan pekerjaan konstruksi meliputi pelaksanaan fisik, pengawasan, uji coba, dan penyerahan hasil akhir pekerjaan.

2. Pelaksanaa beserta pengawasan pekerjaan konstruksi dilakukan berdasarkan hasil perencanaan teknik.

3. Pelaksanaan beserta pengawasan dilaksanakan melalui kegiatan penyiapan, pengerjaan, dan pengakhiran.

\section{B. Pemeriksaan Terhadap Perencanaan Pekerjaan Konstruksi \\ Pemeriksaan dilakukan terhadap paket} yang diperiksa sesuai SPT. Dalam melakukan pemeriksaan, acuan desain yang digunakan adalah Standar Nasional Indonesia (SNI) dan/atau standar keteknikan terkait dalam rangka pemenuhan terhadap ketaatan, kebenaran dan kelengkapan proses, produk dan manfaat desain.

Lingkup pemeriksaan perencanaan pekerjaan konstruksi antara lain penilaian terhadap harga konstruksi, tipe atau jenis konstruksi dan perhitungan desainnya, serta dokumen pengadaan yang terdiri dari gambar desain dan dokumen administrasi sebagai produk perencanaan penunjang pelaksanaan pekerjaan. Bila penilaian terhadap kewajaran harga konstruksi, analisis pemilihan tipe atau jenis konstruksi dan perhitungan desain mengindikasikan inefisiensi, maka direkomendasikan untuk dilakukan value engineering. Berlandaskan azas manfaat bahwa pembangunan adalah investasi pemerintah maka perencanaan harus menunjukan tujuan fungsional dan manfaat fungsional yang terukur.

Produk perencanaan konstruksi meliputi hal-hal sebagai berikut : 
1. Tujuan fungsional (outcome) proyek pembangunan.

Adalah manfaat langsung terhadap masyarakat dan lingkungan yang menjadi tujuan dari pembangunan, terukur, logik, dan dikomunikasikan dengan masyarakat pemanfaat serta sektor pembangunan terkait lainnya. Sektor pembangunan terkait lainnya menunjang pembangunan tersebut dengan keterpaduan program

2. Manfaat fungsional (dampak) proyek pembangunan.

Adalah manfaat lanjut yang berdampak pada masyarakat dan lingkungan yang menjadi tujuan dari pembangunan yang terukur, logik dan dikomunikasikan dengan masyarakat pemanfaat serta sektor pembangunan terkait lainnya. Sektor pembangunan terkait lainnya menunjang pembangunan tersebut dengan program yang "link and match" sehingga menjadi program yang integrated;

3. Keluaran Perencanaan Umum (output); Adalah jenis konstruksi yang diperlukan dalam rangka mendapatkan manfaat fungsional;

4. Tahun perencanaan dikaitkan dengan tahun pelaksanaan;

5. Perhitungan desain (design note);

6. Gambar desain dan legalitasnya;

7. Umur rencana bangunan;

8. Dokumen Pengadaan (berdasar Keppres 80 Tahun 2003 atau guidelines negara donor):

a. Dokumen Penilaian Kualifikasi dan Dokumen Evaluasi Penawaran;

b. Dokumen Pemilihan Penyedia Jasa:

1) Instruksi kepada penawar

2) Syarat-syarat umum

3) Syarat-syarat khusus

4) Spesifikasi teknis umum

5) Spesifikasi teknis khusus

6) Gambar

9. Engineer's Estimate

\section{Pemeriksaan Terhadap Pengadaan Tahap Pra Kontrak Sampai Dengan Tandatangan Kontrak}

Pemeriksaan terhadap pengadaan dilakukan dalam rangka pemenuhan ketaatan, kelengkapan, kebenaran, dan efisiensi, ekonomi yang meliputi tahapan persiapan pengadaan, pemilihan penyedia jasa dan tandatangan kontrak yang berkaitan dengan kualifikasi penyedia jasa dan terhadap pengertian "the lowest evaluated substantially responsive bid, from responsible bidder" meliputi :

1. Ketentuan Pelelangan Terbatas dan Pelelangan Umum dengan Prakualifikasi.

2. Ketentuan Penunjukan Langsung.

3. Tata cara penilaian kualifikasi dan evaluasi penawaran khususnya evaluasi teknis.

\section{Pemeriksaan Terhadap Pengendalian Pelaksanaan Kontrak}

Pemeriksaan dalam rangka pemenuhan ketaatan, kelengkapan, kebenaran, efisiensi, ekonomi, terhadap pengendalian kualitas, waktu, dan biaya dengan memeriksa kebenaran pelaksanaan pengendalian atas instrumen pengendalian dan aplikasinya. Lingkup pemeriksaan tersebut meliputi:

1. Organisasi Pelaksanaan, Pengguna Jasa, Penyedia Jasa Konsultansi (manajemen konstruksi dan /atau supervisi) dan Penyedia Jasa Pelaksanaan Konstruksi;

2. Penyerahan lapangan;

3. Pre Construction Meeting (Rapat pra pelaksanan):
a. Construction
Method
(Metode pelaksanaan):
1) Technical Analysis (Analisis pendekatan teknis);
2) Time Schedule (Jadwal waktu pelaksanaan);
3) Material Schedule (Jadwal waktu penyediaan material);
4) Equipment Schedule (Jadwal waktu penyediaan peralatan);
5) Man Power Schedule (Jadwal waktu penyediaan tenaga kerja);
6) Cash Flow Schedule (Jadwal waktu penerimaan dan pengeluaran uang).

b. Program Mutu;

1) Rencana Mutu Proyek;

2) Rencana Mutu Kontrak.

c. Pelaksanaan Program Mutu.

d. Prosedur Kegiatan Baku

(SOP) Pelaksanaan .

4. Pemeriksaan metode pelaksanaan yang berpengaruh pada pengendalian kualitas, waktu, dan biaya. Pemeriksaan metode 
pelaksanaan yang berpengaruh pada pengendalian kualitas, waktu, dan biaya dalam rangka pemenuhan ketaatan, kelengkapan, kebenaran, efisiensi dan ekonomi, dengan memeriksa kebenaran pelaksanaan pengendalian yang didasarkan atas instrumen pengendalian dan penerapannya sebagai berikut:

a. Pemeriksaan kesesuaian antara metode pelaksanaan yang ditawarkan/kontrak dan metode pelaksanaan yang digunakan;

b. Penyimpangan yang terjadi (bila ada) menjadi tanggung jawab pelaksana konstruksi (penyedia jasa);

c. Pemeriksaan terhadap perubahan metode pelaksanaan yang telah disepakati pengguna jasa dan penyedia jasa terkait dengan pengaruh terhadap kualitas, waktu, dan biaya;

d. Pemeriksaan terhadap metode pelaksanaan, metode kerja, peralatan dan bahan yang digunakan apabila mengindikasikan adanya inefisiensi, maka direkomendasikan untuk dilakukan value engineering;

e. Pemeriksaan terhadap kontrak kritis dengan mekanisme "show cause meeting";

f. Pemeriksaan terhadap perubahan metode pelaksanaan akibat keterlambatan penyiapan lahan, perubahan desain, dan lain-lain.

\section{E. Pemeriksaan Terhadap Pelaksanaan Fisik Konstruksi}

Pemeriksaan dalam rangka pemenuhan ketaatan, kelengkapan, kebenaran, efisiensi dan ekonomis, meliputi:

\section{Pemeriksaan Keteknikan}

Pemeriksaan terhadap pemenuhan persyaratan keselamatan umum, konstruksi bangunan, mutu hasil pekerjaan, mutu bahan dan/atau komponen bangunan, dan mutu peralatan sesuai dengan standar atau norma yang berlaku. Lingkup pemeriksaan meliputi:

a. Metode pelaksanaan

Pemeriksaan terhadap metode pelaksanaan dan metode kerja bila dinilai terjadi inefisiensi direkomendasikan untuk dilakukan value engineering b. Personil

1) Pemeriksaan terhadap pemenuhan kualitas dan kuantitas tenaga kerja (Sertifikat Keahlian Kerja dan Sertifikat Keterampilan Kerja).

2) Pemeriksaan terhadap perhitungan kebutuhan tenaga kerja.

3) Pemeriksaan terhadap penyusunan jadwal waktu penyediaan tenaga kerja.

4) Pemeriksaan terhadap efektivitas penyediaan tenaga kerja.

c. Peralatan

1) Pemeriksaan terhadap jenis, jumlah, kapasitas dan kondisi peralatan/umur ekonomis;

2) Pemeriksaan terhadap perhitungan kebutuhan peralatan dan kesesuaian penggunaan peralatan dengan peruntukannya, bila perlu disarankan dilakukan value engineering;

3) Pemeriksaan terhadap penyusunan jadwal waktu penyediaan peralatan;

4) Pemeriksaan terhadap realisasi/perubahan pengerahan peralatan;

5) Pemeriksaan terhadap efektivitas penggunaan peralatan.

d. Mutu Bahan

1) Pemeriksaan terhadap pemenuhan persyaratan bahan baku dan bahan campuran;

2) Pemeriksaan terhadap perhitungan kebutuhan bahan baku dan bahan campuran;

3) Pemeriksaan terhadap penyusunan program pengadaan bahan baku;

4) Pemeriksaan terhadap realisasi program pengadaan/penggunaan bahan baku;

5) Pemeriksaan terhadap kemungkinan inovasi penggunaan bahan yang terkait dengan value engineering

e. Mutu Produk

Pemeriksaan pemenuhan persyaratan kualitas konstruksi dan komponennya dengan melakukan pengujian menggunakan standar keteknikan SNI atau standar dari Negara donor.

1) Pemeriksaan terhadap kualitas:

a) Hasil test kualitas produk dan standar yang digunakan; 
b) Sistem uji kualitas produk dan pengambilan sampelnya;

c) Hasil evaluasi test poduk dan metodenya;

d) Bahas metode pengujian dan pengambilan sampel.

Apabila dalam pemeriksaan sistem sampling tidak dapat dilaksanakan, maka uji mutu dilaksanakan dengan uji petik pada bagian yang ditentukan oleh tim bersama pengguna jasa. Berdasarkan hasil uji petik:

a) Dalam batas toleransi disarankan untuk dilakukan koreksi pembayaran pada bagian yang ditentukan bersama, dan untuk bagian lainnya disarankan kepada Atasan untuk dilakukan pengujian bersama antara pengguna dan penyedia jasa yang disaksikan oleh pihak Itjen;

b) $\mathrm{Di}$ bawah batas toleransi, disarankan seluruh pekerjaan ditolak dan harus diperbaiki sesuai spesifikasi teknis atau disarankan kepada Atasan untuk dilakukan pengujian bersama antara pengguna dan penyedia jasa yang disaksikan oleh pihak Itjen;

c) Hasil tindak lanjut disampaikan oleh Atasan yang bersangkutan kepada Menteri PU dengan tembusan Inspektur Jenderal Departemen Pekerjaan Umum

2) Pemeriksaan terhadap Kuantitas :

a) Pemeriksaan terhadap prosedur permohonan dan persetujuan untuk memulai pelaksanaan setiap tahap kegiatan:

(1) Permohonan dan persetujuan yang diberikan untuk tahapan pekerjaan dalam satu kegiatan. Persetujuan menjadi dasar pelaksanaan tahap berikutnya;

(2) Bila mekanisme prosedur tidak dipenuhi, periksa hasil test kualitas pekerjaan.
(3) Hasil pelaksanaan pekerjaan (uji produk) secara visual dan laboratorium:

b) Pemeriksaan terhadap pengukuran hasil pelaksanaan untuk pembayaran;

(1) Cara mengukur kuantitas berdasar dokumen kontrak dan pelaksanaannya;

(2) Waktu pengukuran, hasil pengukuran dan back up datanya;

(3) Buku Harian.

c) Pemeriksaan terhadap perintah perubahan

(1) Pemeriksaan terhadap perubahan menambah, mengurangi, dan menghapus kuantitas :

(a) Legalitas surat perintah perubahan (CCO);

(b) Dasar perintah perubahan;

(c) Kebenaran volume hasil perubahan;

(d) Apakah ada pengaruh terhadap perubahan harga satuan, waktu, dan kualitas

(2) Pemeriksaan terhadap perubahan sifat atau kualitas atau jenis pekerjaan :

(a) Legalitas surat perintah perubahan;

(b) Dasar perintah perubahan;

(c) Kebenaran kualitas hasil perubahan;

(d) Apakah ada pengaruh terhadap perubahan harga satuan, waktu, dan biaya.

(3) Pemeriksaan terhadap perubahan lokasi atau dimensi bagian-bagian pekerjaan:

(a) Legalitas surat perintah perubahan;

(b) Dasar perintah perubahan; 
(c) Dasar perubahan

perhitungan tersebut.

(4) Pemeriksaan terhadap perubahan urutan atau waktu konstruksi bagian-bagian Pekerjaan:

(a) Legalitas surat perintah perubahan;

(b) Dasar perintah perubahan;

(c) Pengaruh terhadap biaya dan waktu.

(d) Pemeriksaan terhadap pekerjaan spesifik

Untuk pekerjaan spesifik antara lain :

1) Pengerukan;

2) Penggalian tanah lunak;

3) Reklamasi/penimbunan tanah rawa; harus diperhatikan metode perhitungan kuantitas hasil pelaksanaan untuk pembayaran

2. Pemeriksaan terhadap keamanan, keselamatan dan kesehatan tempat kerja

a. Pemeriksaan terhadap pemenuhan kewajiban penyedia jasa meliputi:

1) Pelaksaan pedoman $\mathrm{K} 3$;

2) Sertifikat kompetensi K3 Petugas Penyedia Jasa (safety officer) dan lingkup tugasnya;

3) Tempat kerja, peralatan, lingkungan kerja dan tata cara kerja, termasuk pemasangan tanda K3 (tanda larangan, tanda petunjuk, tanda perhatian dan rambu-rambu lainnya);

4) Pemenuhan kewajiban dalam tanggung jawab terhadap kecelakaan dan gangguan para pekerja;

5) Penyelenggaraan mekanisme Pertolongan Pertama Pada Kecelakaan (PPPK) berserta pelengkap penunjangnya :

a) SOP PPPK;

b) Kerjasama dengan Puskesmas setempat;

c) Tim PPPK proyek;

d) Sistem pelaporan kecelakaan.

b. Pemeriksaan terhadap pemenuhan kewajiban pengguna jasa, meliputi :

1) Pelaksanaan pedoman K3;
2) Pelaksanaan pengawasan terhadap penyelenggara K3 (konstruksi) oleh penyedia jasa;

3) Pelaksanaan penghentian pekerjaan apabila penyedia jasa dinilai tidak melaksanakan/menyimpang dari ketentuan

4) Pelaporan kepada Atasan langsung atas terjadinya kecelakaan kerja;

5) Pelaksanaan tanggung jawab terhadap kecelakaan, apabila penyedia jasa tidak memenuhi kewajibannya.

c. Pemeriksaan terhadap organisasi panitia pembina keamanan, keselamatan dan kesehatan kerja (safety committee), meliputi :

1) Organisasi kepanitiaan;

2) Unsur kepanitiaan, tugas dan tanggung jawabnya;

3) Jumlah petugas keselamatan kerja;

4) Hubungan kerja dengan Pengguna Jasa;

5) Jadwal kerja petugas keselamatan kerja;

6) Sertifikasi kompetensi petugas keselamatan kerja;

7) Pemeriksaan kesehatan kepada para pekerja;

8) Tenaga kerja di bawah umur 18 tahun;

9) Pembuatan rencana organisasi dan pertolongan pertama pada kecelakaan.

3. Pemeriksaan terhadap perlindungan sosial tenaga kerja

Pemeriksaan terhadap pemenuhan persyaratan perlindungan tenaga kerja oleh penyedia jasa dengan ketentuan bahwa:

a. Penyedia Jasa harus mengasuransikan tenaga kerja konstruksi terhadap risiko kecelakaan dan harus dapat menunjukkan polis asuransi kepada Penggunan Jasa beserta tanda terima pembayaran premi terbaru.

b. Penyedia Jasa harus dapat menunjukkan bukti polis asuransi kepada Pengguna Jasa sebelum dimulai pekerjaan.

4. Pemeriksaan terhadap pemenuhan persyaratan tata lingkungan setempat dan pengelolaan lingkungan hidup

a. Pemeriksaan terhadap pemenuhan persyaratan analisis mengenai dampak lingkungan hidup (AMDAL), meliputi : 
1) Dokumen AMDAL apakah sudah mencakup uraian tujuan dan kegunaan rencana kegiatan dengan manfaat pembangunan;

2) Apakah pelaksanaan AMDAL sudah mengacu pada peraturan perundangundangan mengenai lingkungan, dan tata ruang;

3) Komponen rencana kegiatan dan lingkungan yang berpotensi terkena dampak;

4) Rencana kegiatan dan metode yang digunakan;

5) Rona lingkungan awal (bagaimana kondisi awal);

6) Peta lokasi kegiatan.

b. Pemeriksaan terhadap Penilaian dan persetujuan dari AMDAL

c. Pemeriksaan apakah izin pembangunan sudah dilengkapi dengan rencana kelola pengelolaan lingkungan (RKL) dan rencana pemantauan lingkungan (RPL). Dokumen Rencana Pengelolaan Lingkungan (RKL) dan Rencana Pemantauan Lingkungan (RPL) sesuai persyaratan.

d. Pemeriksaan terhadap adanya persetujuan Komisi ANDAL (Pusat/Provinsi/ Kabupaten tergantung pada lingkup pembangunannya):

1) Surat pengajuan persetujuan;

2) Kelengkapan administrasi;

3) Hasil studi AMDAL;

4) Keahlian dan sertikasi penyusun AMDAL.

e. Pemeriksaan terhadap paket pembangunan yang wajib melakukan AMDAL.

1) Besaran dan jumlah paket pekerjaan yang dibawah 50 Milyard dan berpotensi mempunyai dampak lingkungan harus mempunyai RKL dan RPL;

2) Total paket pekerjaan secara series dengan total pekerjaan diatas Rp 50

Milyard harus mempunyai AMDAL.

f. Pemeriksaan pelaksanaan dan pelaporan upaya pengelolaan lingkungan (UKL) dan upaya pemantauan lingkungan (UPL);

g. Pemeriksaan terhadap upaya pelibatan peran masyarakat dalam penyusunan AMDAL;
1) Berapa kali dilaksanakan Pertemuan Konsultasi Masyarakat.;

2) Siapa yang mewakili masyarakat;

3) Apakah ada LSM yang hadir pada PKM;

h. Pemeriksaan terhadap pelaporan dan pengumuman pemrakarsa pembangunan mengenai rencana kegiatan yang akan dilakukan, jenis dan volume limbah serta penanganannya dan kemungkinan dampak lingkungan hidup yang ditimbulkan;

1) Pengumumun kegiatan pembangunan;

2) Limbah yang akan diproduksi oleh kegiatan pembangunan;

3) Tingkat kebisingan peralatan yang menggangu lingkungan

4) Tingkat gangguan suara akibat penggunaan bahan peledak yang mengganggu lingkungan;

5) Jam kerja kegiatan pembangunan;

6) Lalu lintas kendaraan berat yang harus melewati lingkungan pemukiman masyarakat.

i. Pemeriksaan terhadap upaya akomodasi masukan masyarakat yang ditujukan ke instansi yang bertanggung jawab di bidang lingkungan.

1) Masukan masyarakat masalah lingkungan.

2) Sistim tanggapan terhadap keluhan masyarakat.

\section{F. Pemeriksaan Terhadap Administrasi} Keuangan

1. Pemeriksaan terhadap pelaksanaan tertib administrasi keuangan meliputi:

a. Pemeriksaan kebenaran semua perhitungan bersama atas prestasi pekerjaan dan back up datanya, mulai dari MC 0 sampai dengan MC 100 (bila sudah selesai);

b. Pemeriksaan terhadap Berita Acara Pemeriksaan Bersama (Mutual Check) dan lampirannya antara lain gambar pelaksanaan, pemenuhan spesifikasi teknik, metode pengukuran, rumusan perhitungan volume;

c. Pemeriksaan kebenaran nilai pembayaran antara lain:

1) Prestasi saat ini dan yang lalu;

2) Harga Satuan Timpang;

3) Porsi Sumber Dana (APBN dan Loan). 
2. Pemeriksaan terhadap penyesuaian harga kontrak (Eskalasi Harga) dengan memeriksa kebenaran pengambilan indeks, volume dan penerapan rumus;

3. Pemeriksaan kebenaran pengenaan pajak, pengembalian uang muka, dan jaminan pemeliharaan (Retention Money);

4. Pemeriksaan terhadap denda (bila ada);

5. Pemeriksaan terhadap kompensasi Kompensasi merupakan pembayaran kepada penyedia jasa atas cidera janji pengguna jasa meliputi:

a. Dasar pemberian kompensasi;

b. Data penunjang/bukti proses pemberian kompensasi;

c. Dokumen negosiasi pemberian kompensasi;

d. Kewenangan pejabat yang menyetujui kompensasi.

\section{G. Pemeriksaan Terhadap Manfaat}

Pemeriksaan manfaat dilakukan terhadap realisasi kegiatan berdasarkan perencanaan meliputi aspek teknis, ekonomis, dan sosial.

1. Pemeriksaan terhadap aspek teknis:

a. Standar perhitungan disain yang digunakan.

b. Masukan hasil survey investigasi yang digunakan dalam perhitungan disain;

c. Perencanaan teknis (disain);

d. Perubahan perencanaan dan tindak lanjutnya;

e. Fungsi konstruksi pada saat pemeriksaan dan dibuat prakiraan fungsi konstruksi setelah FHO.

2. Pemeriksaan terhadap aspek ekonomis, meliputi:

a. Perhitungan kelayakan dengan benefit cost ratio, internal rate of return;

b. Kondisi ekonomi yang berkembang;

c. Pengaruh perkembangan ekonomi terhadap perhitungan kelayakan;

d. Pelaksanaan dukungan sektor lain dalam bentuk keterpaduan program.

3. Pemeriksaan terhadap aspek sosial, meliputi:

a. Dokumen peran masyarakat sejak perencanaan sampai dengan operasi dan pemeliharaan; b. Pemerintah daerah dalam operasi dan pemeliharaan.

\section{H. Pemeriksaan Terhadap Kegagalan Konstruksi dan Kegagalan Bangunan} Pemeriksaan terhadap kemungkinan adanya unsur-unsur yang berpotensi mengakibatkan kegagalan konstruksi dan/atau kegagalan bangunan.

1. Pemeriksaan terhadap aspek-aspek yang menyebabkan terjadinya kegagalan pekerjaan konstruksi.

a. Ketentuan tentang kegagalan pekerjaan konstruksi di dalam kontrak dan kesesuaian dengan UU No:18 th 1999 tentang Pekerjaan konstruksi dan PP No. 29 tahun 2000 tentang Penyelenggaraan Pekerjaan konstruksi;

b. Kejadian kegagalan pekerjaan konstruksi dan dokumen evaluasi penyelesaiannya;

c. Pihak yang bertanggung jawab terhadap kegagalan pekerjaan konstruksi;

d. Tindak lanjut atas kejadian kegagalan pekerjaan konstruksi;

e. Tindak lanjut atas kejadian kegagalan pekerjaan konstruksi yang mengakibatkan kerugian dan/atau gangguan terhadap keselamatan umum.

2. Pemeriksaan terhadap aspek-aspek yang menyebabkan terjadinya kegagalan bangunan

a. Ketentuan tentang kegagalan bangunan di dalam kontrak dan kesesuaian dengan UU No. 18 th 1999 tentang Jasa Konstruksi dan PP No. 29 tahun 2000 tentang Penyelenggaraan Pekerjaan Konstruksi;

b. Periksa dokumen perencanaan tentang umur konstruksi;

c. Periksa kejadian kegagalan bangunan dan dokumen evaluasi penyelesaiannya;

d. Periksa waktu pembentukan Tim Penilai Ahli yang ditunjuk untuk masalah kegagalan bangunan dan laporannya;

e. Periksa tindak lanjut atas kejadian kegagalan bangunan yang mengakibatkan kerugian dan/atau gangguan terhadap keselamatan umum;

f. Periksa mekanisme pertanggungan kegagalan bangunan. 
I. Pemeriksaan Terhadap Program dan Pelaksanaan Operasi dan Pemeliharaan (OM)

1. Periksa manual operasi dan pemeliharaan

2. Periksa penyerahan pekerjaan selesai

3. Periksa siapa pengelola operasi dan pemeliharaan

\section{PELAPORAN DAN HASIL}

Hasil pelaksanaan program kerja pemeriksaan konstruksi termasuk tanggapan dari auditi dituangkan ke dalam Laporan Pelaksanaan Program Kerja Pemeriksaan Konstruksi. Untuk selanjutnya dibuat Laporan Hasil Pemeriksaan dalam bentuk surat. Pedoman ini tidak hanya berlaku untuk kontrak perencanaan, pelaksanaan dan pengawasan secara terpisah, namun juga berlaku untuk kontrak terintegrasi dan lainnya (engineering, procurement and construction, design and build, performance based contract, dan sebagainya).

\section{DAFTAR PUSTAKA}

Departemen Pekerjaan Umum Republik Indonesia, 1999, Undang-undang Nomor 18 Tahun 1999 tentang Jasa Konstruksi dan Peraturan Pelaksanaannya

Departemen Pekerjaan Umum Republik Indonesia, 2008, Permen PU No. 14/PRT/M/2007 tentang Pedoman Umum Pemeriksaan Terhadap Penyelenggaraan Pekerjaan Konstruksi Bidang Sarana dan Prasarana Pekerjaan Umum

Presiden Republik Indonesia, 2000, Peraturan Pemerintah Republik Indonesia Nomor 29 Tahun $2000 \quad$ Tentang Penyelenggaraan Jasa Konstruksi 